\title{
A Novel Variant c.97C > T of the Growth Hormone Releasing Hormone Receptor Gene Causes Isolated Growth Hormone Deficiency Type Ib
}

\author{
(D) Assimina Galli-Tsinopoulou ${ }^{1}$, (D) Eleni P. Kotanidou ${ }^{1}$, (D) Aggeliki N. Kleisarchaki ${ }^{1}$, (D) Rivka Kauli ${ }^{2}$, (D) Zvi Laron ${ }^{2}$ \\ ${ }_{1}^{1}$ Aristotle University of Thessaloniki Faculty of Health Sciences, School of Medicine, Papageorgiou General Hospital, $4^{\text {th }}$ Department of \\ Pediatrics, Thessaloniki, Greece \\ ${ }^{2}$ Tel Aviv University Sackler Faculty of Medicine, Schneider Children's Medical Center of Israel, Clinic of Endocrinology and Diabetes Research, \\ Tel Aviv, Israel
}

\section{What is already known on this topic?}

Isolated growth hormone deficiency (IGHD) is a sporadic disease with insufficient or deficient production of growth hormone (GH). IGHD type $1 \mathrm{~b}$ is caused by mutations in either the $\mathrm{GH}-1$ gene or the growth hormone releasing hormone receptor gene.

\section{What this study adds?}

We report a previously undescribed genetic defect, the c.97C > T variant of the growth hormone releasing hormone receptor gene, which results in severe growth retardation, approaching growth arrest, in the homozygous state. The present case provides new data on genetic causes of isolated growth hormone deficiency type $1 \mathrm{~b}$ and describes the phenotype of this novel mutation.

\begin{abstract}
Congenital isolated growth hormone deficiency (IGHD) type $1 \mathrm{~b}$ is an autosomal recessive genetic condition caused by mutations of growth hormone $(\mathrm{GH})-1$ or the growth hormone releasing hormone receptor $(G H R H-R)$ genes. Affected subjects present with symptoms of growth hormone deficiency (GHD) with low but detectable levels of growth hormone (GH), short stature and responsiveness to GH therapy. We describe a 13-month old girl with severe growth failure who showed a low GH response to two GH provocation tests and a modest increase of insulin-like growth factor-1 (IGF-1) to an IGF-1 generation test. Whole exome sequencing revealed a novel homozygous variant of the GHRH-R gene (c.97C > T), leading to a premature stop codon. Administration of recombinant human GH improved linear growth. This is the first report of a c. $97 \mathrm{C}>\mathrm{T}$ mutation of the GHRH-R gene.

Keywords: Congenital isolated growth hormone deficiency, growth hormone releasing hormone receptor, failure to thrive, short stature
\end{abstract}

\section{Introduction}

Isolated growth hormone deficiency (IGHD) is a sporadic disease with a prevalence ranging from 1:3480 to 1:10 000 live births (1). It is defined as an insufficient or deficient production of growth hormone $(\mathrm{GH})$ by the pituitary gland. Its complex etiology involves a spectrum of hypothalamic defects, pituitary abnormalities or combined conditions, which can be structurally detected by brain imaging in only $26.8 \%$ of affected patients (2).
Familial IGHD is classified into four distinct types with different clinical manifestation and inheritance patterns. The two most frequent types of IGHD are types $1 \mathrm{a}$ and $1 \mathrm{~b}$, characterized by an autosomal recessive trait; type 2 is transmitted as an autosomal dominant defect while type 3 appears with an X-linked inheritance pattern. Type 1 a IGHD presents as an entire $G H-1$ gene deletion with undetectable serum GH levels, extremely short stature and possible development of anti-GH antibodies after recombinant human GH administration $(3,4)$. Type $1 \mathrm{~b}$ IGHD presents with a milder phenotype, caused by mutations to either
Address for Correspondence: Assimina Galli-Tsinopoulou MD, Aristotle University of Thessaloniki Faculty of Health Sciences, School of Medicine, Papageorgiou General Hospital, $4^{\text {th }}$ Department of Pediatrics, Thessaloniki, Greece

Phone: + 302310991537 E-mail: agalli@auth.gr ORCID ID: orcid.org/0000-0002-8503-3893

'Copyright 2018 by Turkish Pediatric Endocrinology and Diabetes Society

The Journal of Clinical Research in Pediatric Endocrinology published by Galenos Publishing House.
Conflict of interest: None declared Received: 05.08.2017 Accepted: 14.12 .2017 
the $G H-1$ gene or to the $\mathrm{GH}$ releasing hormone receptor $(G H R H-R)$ gene with low but detectable levels of serum $\mathrm{GH}$, short stature and a positive response to GH therapy with immunologic tolerance (5). Type 2 IGHD patients may also present with low serum GH levels without development of anti-GH antibodies. IGHD-type 3 has been associated with occasional agammaglobulinemia (6)

The GHRH-R gene is located on the short arm of chromosome 7. A number of mutations within the specific locus of the $G H R H-R$ gene have been reported in IGHD type $1 \mathrm{~b}$ subjects, leading to loss of the receptor function and thus to growth failure. We present a novel mutation of the GHRH-R, leading to IGHD type $1 \mathrm{~b}$ in a 13-months old Greek girl, the youngest patient with a GHRH-R mutation reported so far.

\section{Case Report}

A 13-month old girl was admitted to our department due to failure to thrive. She was the second child of healthy, unrelated parents, whose heights were $190 \mathrm{~cm}$ (father) and $175 \mathrm{~cm}$ (mother). An ethical review board approval and informed consent from both parents of the proband presented here were obtained, in accordance with national laws.
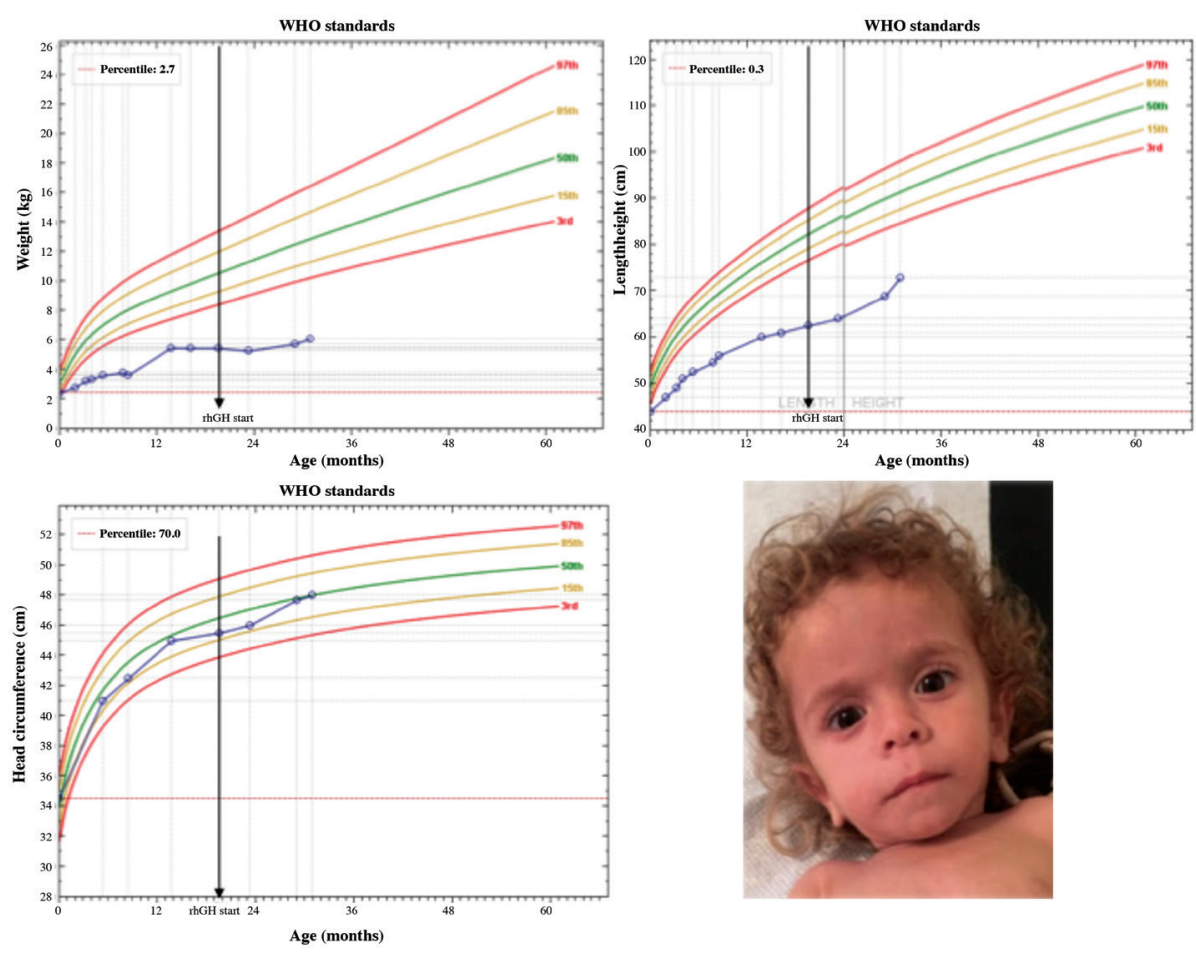

Figure 1. Growth chart for weight-for-age, height-for-age and head circumference-for-age (Anthro World Health Organization software) along with a clinical photograph of the patient at 15 months of age showing typical facial features of a patient with growth hormone deficiency

WHO: World Health Organization 
fontanelles. Hair was very sparse and ears were low set. Nasal bridge was hypoplastic and dental development was significantly retarded (one tooth). Motor milestones were delayed; she was able to sit but could not stand. Systematic clinical examination of the heart, lungs and abdomen did not reveal abnormal findings.

Complete blood count, haemoglobin levels and glucose concentrations as well as renal function were within the normal range for her age. Karyotype analysis showed a normal female genotype of $46 \mathrm{XX}$. Thyroid and adrenal hormone levels were normal. Serological indices for celiac disease or food allergy were negative. Serum GH response to clonidine, glucagon and arginine stimulation tests revealed very poor response, with a peak GH value of 4.77 ng/mL, demonstrating IGHD (Table 1). An IGF-1 generation test after administering $\mathrm{GH}$ at a dose of $33 \mu \mathrm{g} / \mathrm{kg}$ for four consecutive days showed low IGF-1 levels with a modest response (Table 1). After 12 months of GH treatment, serum IGF-1 level rose to $23 \mathrm{ng} / \mathrm{mL}$. Bone age was two months at the chronological age of 13 months. Magnetic resonance imaging of the brain revealed a normal pituitary gland and normal hypothalamus.

At the chronological age of 19 months the patient was administered $\mathrm{GH}$ at a starting dose of $0.28 \mathrm{mg} / \mathrm{kg} / \mathrm{week}$, subcutaneously. After ten months, GH dose was increased to $0.35 \mathrm{mg} / \mathrm{kg} /$ week. At the age of 22 months she started to walk. At the chronological age of 24 months she presented a 12 month phalangeal and a nine month carpal bone age. After ten months of medication she gained $7 \mathrm{~cm}$ in length $(8.14 \mathrm{~cm} / y e a r)$, $300 \mathrm{~g}$ in weight and her head circumference had increased by $2.2 \mathrm{~cm}$. After one year of treatment (at chronological age of 31 months) the patient had achieved a length of $73.5 \mathrm{~cm}\left(<3^{\text {rd }}\right.$ percentile, z-score: -5.2$)$, a weight of $6100 \mathrm{~g}\left(<3^{\text {rd }}\right.$ percentile, z-score: -5.65$)$ and a head circumference of $48 \mathrm{cms}\left(50^{\text {th }}\right.$ percentile, z-score: -0.02) (Figure 1).

\begin{tabular}{|c|c|c|c|c|c|}
\hline \multirow{2}{*}{$\begin{array}{l}\text { Time } \\
\text { (min) }\end{array}$} & \multicolumn{3}{|c|}{ GH (ng/mL) } & \multicolumn{2}{|c|}{ IGF - 1 (ng/mL) } \\
\hline & Clonidine & Glucagon & Arginine & $\begin{array}{l}\text { IGF - } 1 \text { ge } \\
\text { test }\end{array}$ & eration \\
\hline 0 & 0.441 & 1.65 & 1.35 & 0 day & 8.9 \\
\hline 30 & 1.37 & 0.96 & 2.98 & $1^{\text {st }}$ day & 11.3 \\
\hline 60 & 3.45 & 2.3 & 3.63 & $2^{\text {nd }}$ day & 13.4 \\
\hline 90 & 1.1 & 4.77 & 1.18 & $3^{\text {rd }}$ day & 13.6 \\
\hline 120 & 0.595 & 2.03 & 1.1 & $4^{\text {th }}$ day & 11.7 \\
\hline 150 & - & 0.84 & 1.27 & - & - \\
\hline 180 & - & 0.44 & - & - & - \\
\hline
\end{tabular}

GH: growth hormone, IGF-1: insulin-like growth factor 1, min: minute
Due to the facial features of the patient, Silver-Russell syndrome has been suspected. The absence of the clinical criteria of Price et al (7) along with a deletion/ duplication analysis with array genomic hybridization, Silver-Russell syndrome was excluded. Additionally, presence of intrauterine growth retardation, along with facial characteristics and delayed eruption of teeth, could suggest a possible diagnosis of 3M syndrome. Triple whole exome sequencing (WES) of the affected girl and parents (CentoXome GOLD') using Illumina technology was performed. No mutation on CUL7, OBSL1 or CCDC8 genes, the mutations leading to $3 \mathrm{M}$ syndrome were found. A novel homozygous nonsense variant in the GHRH-R gene, the c. $97 \mathrm{C}>\mathrm{T}\left(\mathrm{p} . \mathrm{Gln} 33^{*}\right)$ was detected. The observed variant creates a premature stop codon and is classified as likely pathogenic-class 2 variant. Parental genotyping detected the novel variant in the mother in a heterozygous form, but it was not found in the father. It is suspected that a large deletion not detectable by WES in the paternal allele is present. The detected c. $97 \mathrm{C}>\mathrm{T}$ variant of the GHRH-R gene has never been reported before and not listed, in the CentoMD.

\section{Discussion}

The present report describes an unknown GHRH-R mutation, in an infant girl of Greek origin, with a clinical appearance resembling a SGA state, rather than congenital GHD $(8,9)$. To the best of our knowledge this is the youngest patient described in the literature to date with a mutation of the GHRH-R gene. The patient presented with a skinny appearance and showed a low IGF-1 response to an IGF-1 generation test. These two unexpected findings probably relate to caloric insufficiency caused by placental insufficiency (10), possibly due to the mother smoking throughout the pregnancy.

Some of the causes of congenital IGHD are GHRH-R gene defects. These gene defects are being described more frequently in the literature (11). Currently more than thirtythree mutations in the GHRH-R gene have been shown to cause impaired GHRH-GH-IGF-1 axis function, whereas no mutations in the GHRH gene have been reported. The large majority of these cases showed an autosomal recessive model of inheritance (12). Mutations of GHRH-R, classified into six different types, cause defective GHRH functionality (13). Null-type GHRH-R mutations lead to unmeasurable IGF1 levels and are accompanied by mild ocular disorders (14). Missense GHRH-R variants -such as p.G369V or p.T257Aresult in partial loss of receptor function due to defective ligand binding and milder phenotypes, occasionally 
accompanied by hypoglycemia (15). Splice site mutations of untranslated and coding regions have been reported to lead to gross indels with loss of $5^{\prime}$ regulatory/exon 1 region, leading to fully impaired GHRH-R expression (12). Other splice-disrupting, single nucleotide polymorphisms like intronic mutations, lead to instability of the produced mRNA, truncated GHRH-R and autosomal recessively inherited IGHD (16). Nonsense type mutations lead to lossof-function changes (17), whereas functional variants of the GHRH-R promoter affect promoter activity and thus decrease expression of the receptor gene (18).

Herein, we present a previously undescribed homozygous GHRH-R gene mutation, c. $97 \mathrm{C}>\mathrm{T}$ (p.Gln33*) in a child with IGHD type $1 \mathrm{~b}$. Clinical and biochemical phenotype of the affected individual comprises severe short stature, low weight gain, low maximum GH values after a battery of provocation tests, inadequate response to IGF-1 generation testing, normal brain imaging and growth acceleration after GH therapy. The reported mutation is predicted to lead to a premature stop codon and thus it signals the termination of translation of the relevant messenger RNA. Defective translation of the gene results in a shorter encoded protein and thus an impaired form of GHRH receptor. The novel mutation probably affects the receptor in terms of both sequence and structure, leading to the inhibition of GHRH binding to its receptor and thus to disruption in $\mathrm{GH}$ secretion signaling. According to the recommendations of the American College of Medical Genetics and Genomics, the novel mutant is classified as likely pathogenic, class 2 .

Since the variant was detected in the maternal DNA in heterozygous state, but not in the paternal genome, the precise pattern of inheritance can not be confirmed. A suggested large deletion in the exact region of the paternal GHRH-R locus could explain the inability to detect the mutation via father WES analysis. Nevertheless, based on the finding of a healthy, unaffected heterogyzous mother, it could be assumed that the variant presented here, p.Gln $33^{*}$, represents an autosomal recessive inheritance trait.

Intrauterine growth restriction is closely associated with placental quality, functionality and therefore adequacy. Multiple layers of associations have been suggested for the causes of fetal growth restriction and SGA offspring. In utero exposure to tobacco constitutes a known risk factors for both conditions. From a meta-analytic approach, even exposure to tobacco smoke during pregnancy is associated with low birth weight (19). Exposure of offspring to tobacco metabolites through maternal milk during infancy has also been suggested (20). Nevertheless, cohort studies have provided evidence that maternal smoking during pregnancy or early infantile life exert a long-term negative effect on growth (21). The presented case constitutes a paradigm of mixture between nature and nurture. Apart from the detected defect in $G H R H-R$ gene sequence, in utero environment and after birth conditions have contributed to the phenotype. Synergistic effects of genetics and epigenetic conditions are not fully understoood and remain to be elucidated.

In conclusion, we report a novel homozygous c.97C > T (p.Gln33*) GHRH-R mutation determined in a Greek infant girl with IGHD. Heterozygosity of the reported variant was not associated with pathological phenotypes in the unaffected family member c. $97 \mathrm{C}>\mathrm{T}$.

\section{Ethics}

Informed Consent: Written parental consent for this case report has been given.

Peer-review: Externally peer-reviewed.

\section{Authorship Contributions}

Surgical and Medical Practices: Assimina Galli-Tsinopoulou, Aggeliki N Kleisarchaki, Rivka Kauli, Zvi Laron, Concept: Assimina Galli-Tsinopoulou, Design: Assimina GalliTsinopoulou, Eleni P. Kotanidou, Zvi Laron, Data Collection or Processing: Eleni P. Kotanidou, Aggeliki N. Kleisarchaki, Rivka Kauli, Analysis or Interpretation: Rivka Kauli, Assimina Galli-Tsinopoulou, Zvi Laron, Literature Search: Eleni P. Kotanidou, Aggeliki N. Kleisarchaki, Assimina GalliTsinopoulou, Writing: Assimina Galli-Tsinopoulou, Eleni P. Kotanidou, Aggeliki N. Kleisarchaki, Rivka Kauli, Zvi Laron.

Financial Disclosure: Authors have no financial disclosure to declare.

\section{References}

1. Thomas M, Massa G, Craen M, de Zegher F, Bourguignon JP, Heinrichs C, De Schepper J, Du Caju M, Thiry-Counson G, Maes M. Prevalence and demographic features of childhood growth hormone deficiency in Belgium during the period 1986-2001. Eur J Endocrinol 2004;151:6772.

2. Maghnie M, Lindberg A, Koltowska-Häggström M, Ranke MB. Magnetic resonance imaging of CNS in 15,043 children with GH deficiency in KIGS (Pfizer International Growth Database). Eur J Endocrinol 2013;168:211-217

3. Cogan JD, Phillips JA 3 rd. GH1 gene deletions and IGHD type 1A. Pediatr Endocrinol Rev 2006;3(Suppl 3):480-488.

4. Laron Z, Kelijman M, Pertzelan A, Keret R, Shoffner JM, Parks JS. Human growth hormone gene deletion without antibody formation or growth arrest during treatment--a new disease entity? Isr J Med Sci 1985;21:999-1006.

5. Baumann G. Genetic characterization of growth hormone deficiency and resistance: implications for treatment with recombinant growth hormone. Am J Pharmacogenomics 2002;2:93-111 
6. Wit JM, Oostdijk W, Losekoot M, van Duyvenvoorde HA, Ruivenkamp CA, Kant SG. MECHANISMS IN ENDOCRINOLOGY: Novel genetic causes of short stature. Eur J Endocrinol 2016;174:145-173. Epub 2015 Nov 17

7. Price SM, Stanhope R, Garrett C, Preece MA, Trembath RC. The spectrum of Silver-Russell syndrome: a clinical and molecular genetic study and new diagnostic criteria. J Med Genet 1999;36:837-842.

8. Laron Z. Deficiencies of growth hormone and somatomedins in man. Spec Top Endocrinol Metab 1983;5:149-199.

9. Smuel K, Kauli R, Lilos P, Laron Z. Growth, development, puberty and adult height before and during treatment in children with congenital isolated growth hormone deficiency. Growth Horm IGF Res 2015;25:182-188. Epub 2015 May 12

10. Hawkes CP, Grimberg A. Insulin-Like Growth Factor-I is a Marker for the Nutritional State. Pediatr Endocrinol Rev 2015;13:499-511.

11. Aguiar-Oliveira MH, Souza AHO, Oliveira CRP, Campos VC, OliveiraNeto LA, Salvatori R. MECHANISMS IN ENDOCRINOLOGY: The multiple facets of GHRH/GH/IGF-I axis: lessons from lifetime, untreated, isolated GH deficiency due to a GHRH receptor gene mutation. Eur J Endocrinol 2017;177:85-97. Epub 2017 Apr 20

12. Kale S, Budyal S, Kasaliwal R, Shivane V, Raghavan V, Lila A, Bandgar $\mathrm{T}$, Shah N. A novel gross indel in the growth hormone releasing hormone receptor gene of Indian IGHD patients. Growth Horm IGF Res 2014;24:227-232. Epub 2014 Aug 7

13. Corazzini V, Salvatori R. Molecular and clinical aspects of GHRH receptor mutations. Endocr Dev 2013;24:106-117. Epub 2013 Feb 1

14. Faro ACN, Pereira-Gurgel VM, Salvatori R, Campos VC, Melo GB, Oliveira F, Oliveira-Santos AA, Oliveira CRP, Pereira FA, Hellströem A, Oliveira-Neto LA, Valenca EHO, Aquiar-Oliveira MH. Ocular findings in adult subjects with an inactivating mutation in $\mathrm{GH}$ releasing hormone receptor gene. Growth Horm IGF Res 2017;34:8-12. Epub 2017 Apr 21
15. Gregory LC, Alatzoglou KS, McCabe MJ, Hindmarsh PC, Saldanha JW, Romano N, Le Tissier P, Dattani MT. Partial Loss of Function of the GHRH Receptor Leads to Mild Growth Hormone Deficiency. J Clin Endocrinol Metab 2016;101:3608-3615. Epub 2016 Aug 8

16. Marui S, Trarbach EB, Boguszewski MC, França MM, Jorge AA, Inoue $\mathrm{H}$, Nishi MY, de Lacerda Filho L, Aguiar-Oliveira MH, Mendonca BB, Arnhold IJ. GH-releasing hormone receptor gene: a novel splicedisrupting mutation and study of founder effects. Horm Res Paediatr 2012;78:165-172. Epub 2012 Oct 10

17. Sıklar Z, Berberoğlu M, Legendre M, Amselem S, Evliyaoğlu O, Hacıhamdioğlu B, Savaş Erdeve S, Oçal G. Two siblings with isolated GH deficiency due to loss-of-function mutation in the GHRHR gene: successful treatment with growth hormone despite late admission and severe growth retardation. J Clin Res Pediatr Endocrinol 2010;2:164167. Epub 2010 Nov 6

18. Inoue $\mathrm{H}$, Kangawa $\mathrm{N}$, Kinouchi A, Sakamoto Y, Kimura C, Horikawa R, Shigematsu Y, Itakura M, Ogata T, Fujieda K; Japan Growth Genome Consortium. Identification and functional analysis of novel human growth hormone-releasing hormone receptor (GHRHR) gene mutations in Japanese subjects with short stature. Clin Endocrinol (Oxf) 2011;74:223-233.

19. Inamdar AS, Croucher RE, Chokhandre MK, Mashyakhy MH, Marinho VC. Maternal Smokeless Tobacco Use in Pregnancy and Adverse Health Outcomes in Newborns: A Systematic Review. Nicotine Tob Res 2015;17:1058-1066. Epub 2014 Dec 22

20. Shenassa ED, Wen X, Braid S. Exposure to Tobacco Metabolites via Breast Milk and Infant Weight Gain: A Population-Based Study. J Hum Lact 2016;32:462-471. Epub 2015 Dec 7

21. Muraro AP, Gonçalves-Silva RM, Moreira NF, Ferreira MG, Nunes-Freitas AL, Abreu-Villaça Y, Sichieri R. Effect of tobacco smoke exposure during pregnancy and preschool age on growth from birth to adolescence: a cohort study. BMC Pediatr 2014;14:99. 